\title{
Origin and Geochemical Evolution of Formation Water in the Dameigou Shale Gas Reservoir in Northern Qaidam Basin
}

\author{
Xiaoshun Cui ${ }^{1,2}$, Zhaoxian Zheng', 2*, Pucheng Zhu ${ }^{1,2}$, Hongda Zhang ${ }^{3}$, \\ Xufeng $\mathrm{Li}^{4}$, Zongyu Chen ${ }^{1,2}$ \\ ${ }^{1}$ Institute of Hydrogeology and Environmental Geology, Chinese Academy of Geological Sciences, \\ Shijiazhuang, Hebei, China \\ ${ }^{2}$ Key Laboratory of Groundwater Science and Engineering, Ministry of Natural Resources of the People's Republic \\ of China, Zhengding, China \\ ${ }^{3}$ Oil and Gas Survey, China Geology Survey, Beijing, China \\ ${ }^{4}$ Center for Hydrogeology and Environmental Geology, China Geological Survey, Baoding, China
}

Received: 10 July 2019

Accepted: 3 November 2019

\begin{abstract}
The origin and geochemical evolution of formation water trapped in continental shale of the Dameigou Formation in the Northern Qaidam Basin have been investigated for selecting unique signatures of formation water compared with shallow groundwater and conventional oilfield brines (COB). The formation water, which is trapped in a closed shale with no halite and sylvite in it, has a higher $\mathrm{Cl} / \mathrm{Br}$ ratio (1183.43) than that of seawater (657.89). Furthermore, $\delta^{2} \mathrm{H}(-67 \%)$ and $\delta^{18} \mathrm{O}(-8.1 \%$ ) values of the formation water lies near the local evaporation line. These suggest that the formation water originated from evaporated rainwater. The temperature $\left(>120^{\circ} \mathrm{C}\right)$ of the Dameigou Formation and the vitrinite reflectance values $(1.0-1.3 \%)$ of the shale indicate that thermochemical sulfate reduction (TSR) was responsible for the depletion of $\mathrm{SO}_{4}$ in the formation water. The increased $\mathrm{CO}_{2}$ concentration and $\mathrm{Mg} / \mathrm{Ca}$ ratio in formation water leading by TSR caused kaolinization of plagioclase feldspar and dolomitization, respectively. The formation water depletion in $\mathrm{Ca}$ and $\mathrm{HCO}_{3}$ was caused mainly by calcitization. The $\mathrm{Na} / \mathrm{Ba}$ ion exchange and dissolution of continental borate occurring in the shale-formation water system were vital to the geochemistry of trace elements in formation water. All these geochemical processes have given the formation water distinctive $\delta^{34} \mathrm{~S}-\mathrm{H}_{2} \mathrm{~S}(25.9 \%),{ }^{87} \mathrm{Sr} /{ }^{86} \mathrm{Sr}$ ratio $(0.713842), \mathrm{Ba} / \mathrm{Ca}$ ratio $\left(2.60 \times 10^{-2}\right)$ and $\delta^{11} \mathrm{~B}(1.1 \%)$ signatures compared with $\mathrm{COB}$ in shallow groundwater.
\end{abstract}

Keywords: geochemical process, groundwater monitoring, continental shale, formation water, HFFF indicator

*e-mail: aslangyeah@126.com 


\section{Introduction}

Shale gas has great resource potential $\left(31 \times 10^{12} \mathrm{~m}^{3}\right)$ in China. Development of shale gas was made possible by the successful application of horizontal drilling and high-volume hydraulic fracturing (HVHF) as Chinese gas demand surged, with natural gas consumption increasing by over $15 \%\left(31 \times 10^{9} \mathrm{~m}^{3}\right)$ from 2016 to 2017 [1]. It is estimated that nearly 700 new wells from three major shale gas plays (Fuling, Changning-Weiyuan and Zhaotong) will come online between 2018 and 2020 [2].

Although the success of unconventional gas development has radically changed the energy portfolio of China, the United States, and other countries, environmental concerns regarding the contamination of groundwater by hydraulic fracturing flowback fluids (HFFF) have arisen [3-5] due to the HFFF produced by HVHF containing a large amount of heavy metals and organic matter at toxic concentrations that pose risks to human health [6-9]. A robust methodology focused on hydrochemical and isotopic characteristics of HFFF has been researched in many studies for precise identification of HFFF spills [10-11]. Previous studies [12-13] on the Marcellus Shale reveal that HFFF is enriched in $\mathrm{Na}$ and $\mathrm{Cl}$ composition with high total dissolved solids (TDS) and high $\mathrm{Br} / \mathrm{Cl}$ ratios relative to modern seawater that reflect different degrees of seawater evaporation. Warner et al. stated that diagnostic elemental and isotopic signatures $\left(\mathrm{B} / \mathrm{Cl}>0.001, \delta^{11} \mathrm{~B}=25-31 \%\right.$ ) are useful for characterizing HFFF and distinguishing sources of HFFF in the groundwater in most cases [12]. Chapman et al. suggested that strontium isotopic ratios of Marcellus Shale HFFF define a relatively narrow set of values $\left({ }^{87} \mathrm{Sr} /{ }^{86} \mathrm{Sr}=0.710148-0.712119\right)$ closed to that of seawater and can be used to sensitively differentiate between Marcellus HFFF and other potential sources of contamination into groundwater or surface water [14]. It should be noted from these previous studies that the formation water trapped in marine shale that originated from seawater dominates the hydrochemical and isotopic compositions of HFFF as a result of mixing during fracturing and flowback processes.

A lot of shale gas reservoirs in China such as the Qaidam, Tarim, and Ordos Basins were deposited in continental environments [3]. Thus, the origin of formation water in these shales could be unlike that in most marine shale in the United States [10]. Consequently, the continental shale formation water may have distinctive hydrochemical and isotopic characteristics compared with marine shale formation water after geochemical evolution in geologic history. This issue highlights the need to improve our understanding of the origin and evolution of formation water for selecting distinguishing indicators of HFFF produced from continental shale formations.

Northwest China is an important production base of conventional oil and gas [15]. As well as HFFF, brines produced from conventional oil and gas wells are a potential source of contamination for shallow groundwater [16-17]. For forensic identification of contamination and subsequent groundwater remediation, it is necessary to distinguish between different sources of pollution in groundwater. Therefore, the aim of the present study is to identify the unique hydrochemical and isotopic signatures of formation water that could be taken as HFFF indicators, thus distinguishing it from conventional oil-field brines $(\mathrm{COB})$ in groundwater.

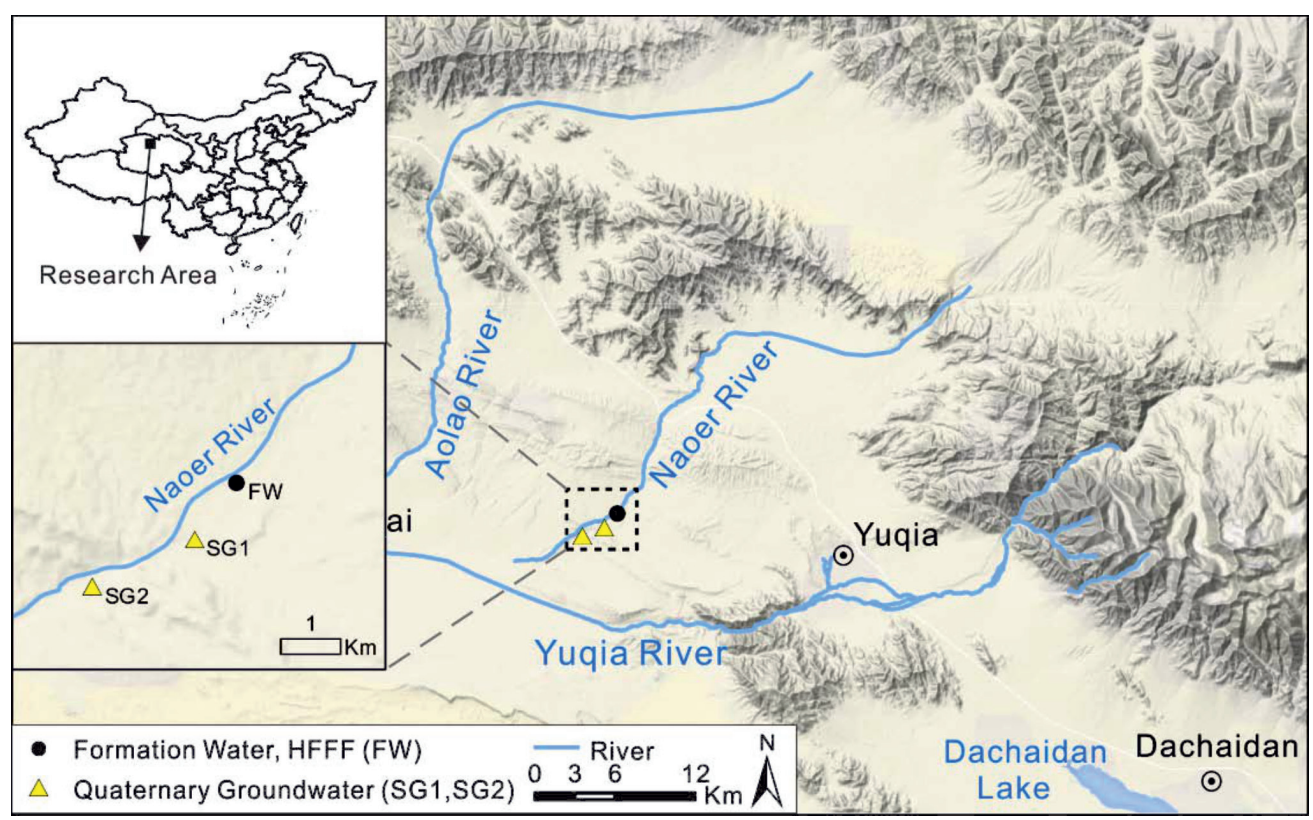

Fig. 1. Sampling locations of the formation water and shallow groundwater in this study are plotted on the topographic map of the research area; formation water of the Dameigou Shale (black circle) was collected from CY1 well; shallow groundwater occurring in the Upper Pleistocene strata was collected from springs (yellow triangles). 
The Dameigou Formation constitutes the most favorable reservoir for shale gas exploitation through the Qaidam Basin [18-19]. The indicators obtained from this study may be applied widely in the Qaidam Basin to identify HFFF in shallow groundwater at large scales within continental shale gas plays. Additionally, the results of this study are significant in risk assessment of drinking groundwater in shale gas plays located in arid and semi-arid areas of northwest China.

\section{Research Area}

The Chai Yel (CY1) well is the first continental shale gas exploration well and is located in Yuqia sag of the northern Qaidam Basin (Fig. 1). The Dameigou Shale, also referred to as the Dameigou Formation, is a Middle Jurassic-age, microfissure-developed, organic-rich and hydrocarbon producing shale that occurs in the subsurface beneath much of the Qaidam Basin [20].

The most promising shale gas intervals (2003-2045 $\mathrm{m})$, which belonged to the $7^{\text {th }}$ member of the Dameigou Formation, were comprised of grey-black shale and carbonaceous shale. A synthesized columnar section of these shale gas intervals in the CY1 well is shown in Fig. 2. These shale intervals are rich in brittle silicate minerals (quartz and feldspar) and clay minerals (kaolinite, illite, andreatitte and chlorite), and poor in carbonate minerals (siderite), with average contents of $42.6 \%, 52.8 \%$ and $4.5 \%$, respectively (Fig. 2) [21]. The organic matters in these shales are high in vitrinite-reflectance (Ro $=1.0-1.3 \%$ ) and are dominated by type II kerogen with a total organic carbon (TOC) content of between $0.3 \%$ and $7.6 \%$ [21]. In addition, micropores are developed in these shales. Pores in organic matters are mainly circular, ranging in size from 1 to $\sim 20 \mu \mathrm{m}$ [21]. The main pore of the mineral skeleton are dissolution pores in grains and intergranular micropore, ranging in size from 1 to $\sim 10 \mu \mathrm{m}[21]$.

Phreatic pore water in the Upper Pleistocene strata, which is the most easily polluted by HFFF, drains as multiple springs along the Naoer River at the south of the CY1 well.

\section{Materials and Methods}

\section{Sample Collection and Treatment}

In this study, two categories of water samples were collected: (1) a sample of formation water from most promising shale gas intervals was collected from CY1 well before hydraulic fracturing in August 2014; (2) samples from two spring discharged from the Upper Pleistocene, located at $1 \mathrm{~km}$ and $2 \mathrm{~km}$ northwest of CY1 well, were collected before hydraulic fracturing in July 2014 (Fig. 1). Formation water was collected, before fracturing, from perforated holes made into the shale formation (2008.0-2012.3 m, 2026.1-2027.9 m, and 2034.8-2037.1 m) using deep penetrating charges.

Samples were filtered through a $0.45 \mu \mathrm{m}$ nylon filter into precleaned HDPE bottles with no head space. Samples for trace element (e.g., Sr, B) were acidified to $\mathrm{pH} 2$ with ultrapure $\mathrm{HNO}_{3}$. Samples for $\mathrm{H}_{2} \mathrm{~S}$ were precipitated to cadmium sulfide by saturated cadmium

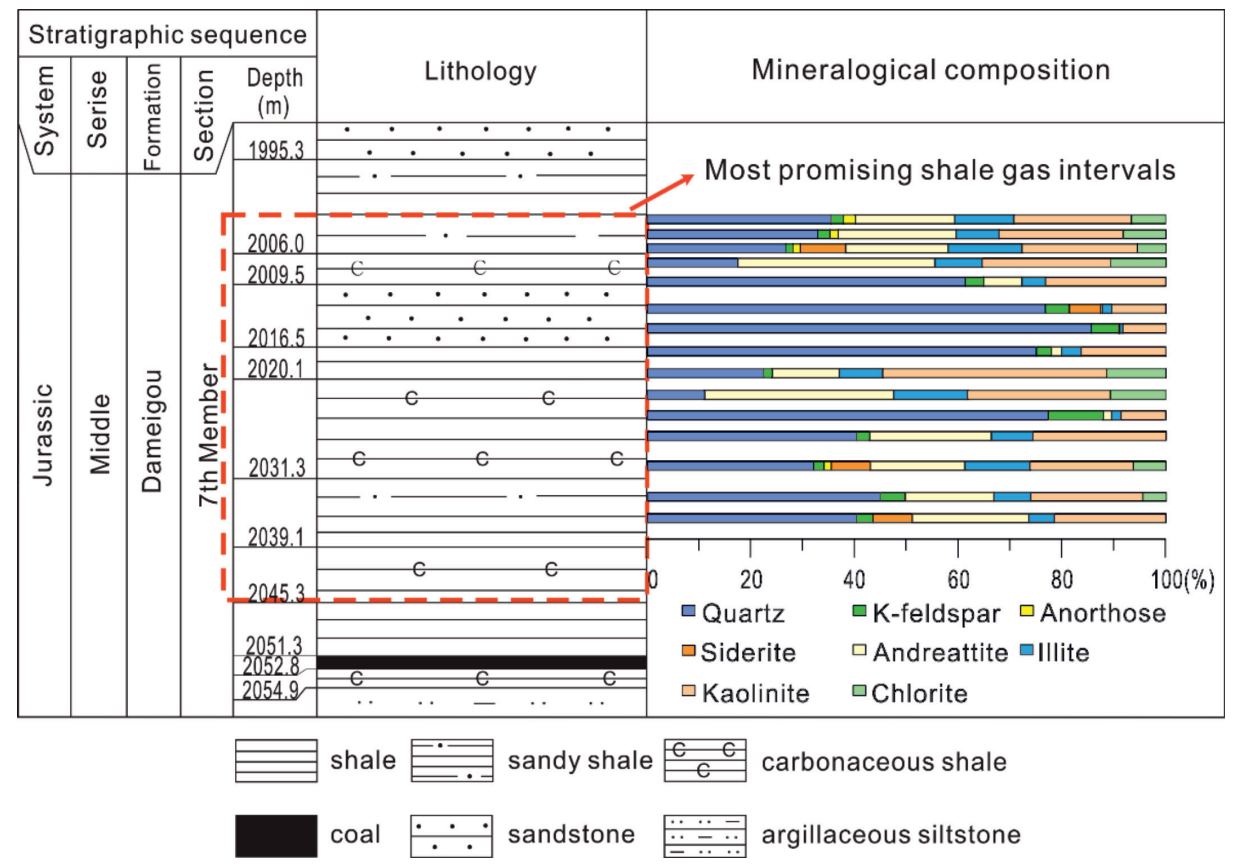

Fig. 2. Synthesized columnar section of most promising shale gas intervals in CY1 well showing stratigraphic sequences, lithology and mineralogical composition. 
acetate at the sampling site. All samples were kept on ice while in the field and refrigerated in the lab at $4^{\circ} \mathrm{C}$ until the analyses were completed.

\section{Analytical Method}

The $\mathrm{HCO}_{3}$ concentration was calculated by acidbase titration. Major anions, except $\mathrm{HCO}_{3}^{-}$, were determined by high-resolution ion chromatography (Thermo Scientific Dionex ICS-4000; precision, $\pm 1 \%$ ), and major cations and minor elements were analyzed by an inductively coupled plasma optical emission spectrometer (PerkinElmer Optima 8300; precision, $\pm 1 \%$ ).

The $\delta \mathrm{D}$ and $\delta^{18} \mathrm{O}$ were analyzed by a Picarro L2130-i Analyzer (precision, $\pm 0.025 / \pm 0.1 \%$ for $\delta^{18} \mathrm{O} / \delta \mathrm{D}$ ). $\delta^{34} \mathrm{~S}$ in $\mathrm{H}_{2} \mathrm{~S}$ were determined by isotope ratio mass spectrometer (IRMS Finnigan-MAT 253). The mass spectrometric uncertainty $(1 \sigma)$ on individual $\delta^{34} \mathrm{~S}$ measurements is better than $0.05 \%$. The ${ }^{87} \mathrm{Sr} /{ }^{86} \mathrm{Sr}$ and $\delta^{11} \mathrm{~B}$ were analyzed by thermal ionization mass spectrometry (IsotopX Phoenix X62) and inductively coupled plasma mass spectrometry (PerkinElmer ELAN DCR-e), respectively. The average ${ }^{87} \mathrm{Sr} /{ }^{86} \mathrm{Sr}$ ratio of NIST SRM 987 and the average ${ }^{11} \mathrm{~B} /{ }^{10} \mathrm{~B}$ ratio of NIST SRM 951 over the period of these analyses was $0.710244 \pm 0.000015(\mathrm{n}=30)$ and $4.0436 \pm 0.0016(n=25)$, respectively.

\section{Evaporation Modeling}

Simulation of evaporation is accomplished by removing water from the chemical system. Water can be specified as an irreversible reactant with a negative reaction coefficient in PHREEQC (Version 3, USGS, Reston, USA). In this study, the REACTION data block is used to simulate concentrations of rain water sampled from the study area by 5 fold, 10 fold, 25 fold, 50 fold, 100 fold, 200 fold, 300 fold, and 367 fold (by removing approximately $80.0 \%, 90.0 \%, 96.0 \%, 98.0 \%, 99.0 \%$, $99.5 \%, 99.6 \%$ and $99.7 \%$ of the water) until the simulated $\mathrm{Br}$ concentration matched the measured $\mathrm{Br}$ concentration of the formation water. The Gibbs free energy increments $(\Delta G)$ for water-rock reactions are little influenced by pressure, but are influenced by temperature. Thus, the temperature of the shale formation during sedimentary history from the previous study was used in this evaporation modeling [22]. The chemical indices of rain water modeled in this modeling are $\mathrm{Na}^{+}, \mathrm{K}^{+}, \mathrm{Ca}^{2+}, \mathrm{Mg}^{2+}, \mathrm{Cl}^{-}, \mathrm{HCO}_{3}^{-}, \mathrm{SO}_{4}^{2-}$, $\mathrm{Br}^{-}$, and $\mathrm{pH}$.

\section{Results}

Hydrochemical and isotopic compositions of formation water from CY1 well along with shallow groundwater from the Quaternary Upper Pleistocene aquifer are shown in Table 1. The data of major ions in the formation water of the Dameigou Shale (Table 1) showed a distinct characteristic from that in shallow groundwater in the study area and COB reported from a previous study [23]. The formation water has a medium level of TDS $(11.50 \mathrm{~g} / \mathrm{L})$, and is distinguished by $\mathrm{Cl}, \mathrm{HCO}_{3}$ and $\mathrm{Na}$ in the dissolved ions (Fig. 3), while the shallow groundwater has a low level of TDS (6.50-6.79 g/L) and is controlled by $\mathrm{Cl}, \mathrm{SO}_{4}, \mathrm{Na}$ and $\mathrm{Mg}$ in the dissolved ions; the $\mathrm{COB}$ has a high level of TDS $(>300.00 \mathrm{~g} / \mathrm{L})$ and is characterized by $\mathrm{Cl}$ and $\mathrm{Na}$ in the dissolved ions (Fig. 3).

Formation water and shallow groundwaters have similar deuterium and oxygen isotopic compositions with $\delta^{2} \mathrm{H}$ ranging from $-51 \%$ to $-58 \%$ and $\delta^{18} \mathrm{O}$ ranging from $-8.7 \%$ to $-5.1 \%$. In comparison to formation water, salt lakes contained more heavily isotopic compositions with $\delta^{2} \mathrm{H}$ ranging from $-15.0 \%$ to $10.0 \%$ and $\delta^{18} \mathrm{O}$ ranging from $2.0 \%$ to $4.2 \% 0$ [23]. The ${ }^{87} \mathrm{Sr} /{ }^{86} \mathrm{Sr}$ ratio of formation water $(0.713842)$ is higher than that of shallow groundwater $(0.712140-0.712273)$ and COB (0.711210-0.711937). Similarly, the $\delta^{34} \mathrm{~S}$ of $\mathrm{H}_{2} \mathrm{~S}$ in formation water $(25.9 \%$ ) is also higher than that in

Table 1. Hydrochemical and isotopic compositions of the formation water from Dameigou Shale (CY1 well) and shallow groundwater from Upper Pleistocene aquifer in shale gas play.

\begin{tabular}{|c|c|c|c|c|c|c|c|c|c|}
\hline \multirow{2}{*}{ Sample } & $\mathrm{Na}$ & K & $\mathrm{Ca}$ & $\mathrm{Mg}$ & $\mathrm{Cl}$ & $\mathrm{SO}_{4}$ & $\mathrm{HCO}_{3}$ & $\mathrm{Br}$ & TDS \\
\hline & \multicolumn{9}{|c|}{$\mathrm{mg} / \mathrm{L}$} \\
\hline FW & 4284 & 376 & 65 & 61 & 5844 & 24 & 2387 & 11.00 & 11496 \\
\hline SG1 & 1796 & 58.1 & 224 & 329 & 2017 & 2052 & 370 & 0.52 & 6791 \\
\hline $\mathrm{SG} 2$ & 1531 & 50.6 & 221 & 377 & 1949 & 2199 & 341 & 0.43 & 6500 \\
\hline \multirow{2}{*}{ Sample } & $\mathrm{Ba}$ & $\mathrm{Sr}$ & $\delta^{11} \mathrm{~B}$ & $\delta^{2} \mathrm{H}$ & $\delta^{18} \mathrm{O}$ & $\delta^{34} \mathrm{~S}-\mathrm{H}_{2} \mathrm{~S}$ & $\mathrm{~T}$ & ${ }^{87} \mathrm{Cr} / 86 \mathrm{Cr}$ & $\mathrm{nH}$ \\
\hline & \multicolumn{2}{|c|}{$\mathrm{mg} / \mathrm{L}$} & \multicolumn{4}{|c|}{$\%$} & ${ }^{\circ} \mathrm{C}$ & $\mathrm{SI} / \mathrm{SI}$ & pn \\
\hline FW & 5.79 & 7.04 & 1.1 & -67 & -8.1 & 25.9 & 57.3 & 0.713842 & 7.0 \\
\hline SG1 & $<0.02$ & 9.43 & 24.4 & -51 & -5.1 & 6.2 & 10.2 & 0.712140 & 8.5 \\
\hline SG2 & $<0.02$ & 8.00 & 26.1 & -68 & -8.7 & 8.6 & 10.8 & 0.712273 & 8.7 \\
\hline
\end{tabular}




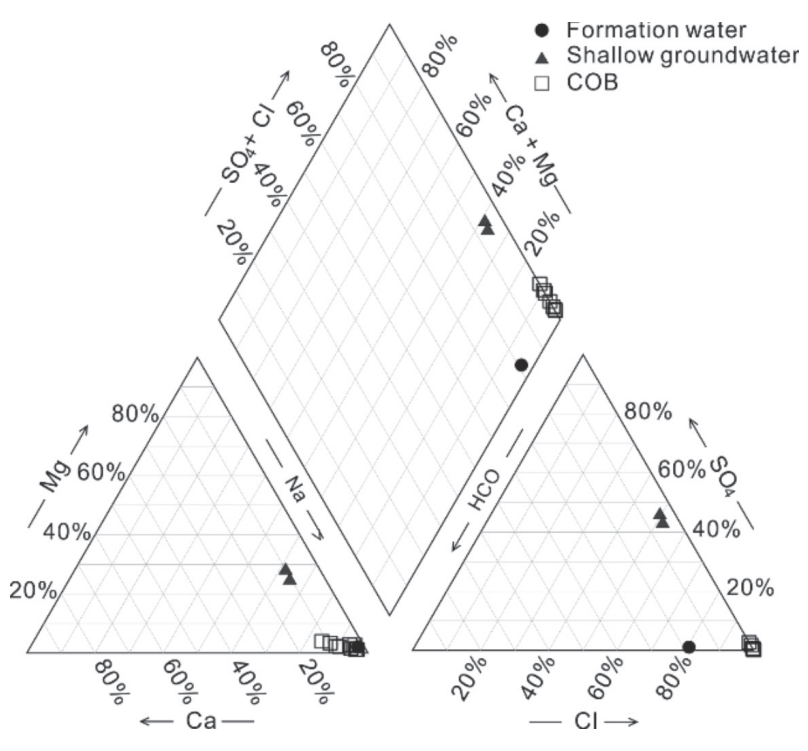

Fig. 3. Piper diagram of the formation water from Dameigou Shale, COB and shallow groundwater.

shallow groundwater $(6.2-8.6 \%)$. On the contrary, the $\delta^{11} \mathrm{~B}$ value of formation water $(1.1 \%$ ) is much lower than that of shallow groundwater (24.4-26.1\%) and $\mathrm{COB}$ $(12.3-31.1 \%)$.

\section{Discussion}

\section{Origin of the Dameigou Formation Water}

The ratio of $\mathrm{Cl}$ versus $\mathrm{Br}$ is an ideal parameter for identifying the origin of solutes, mixing and dilution of brines, and various water-rock interactions without diagenetic alterations [24]. The $\mathrm{Cl} / \mathrm{Br}$ molar ratio (1183.43) and $\mathrm{Cl}$ concentration $(164.62 \mathrm{mM})$ of formation water is lower than that of salt lakes, respectively, (3082.65-28427.89, 2121.97-5336.90 mM) in the northern Qaidam Basin, including Qinghai Lake [23] (Fig. 4a). Furthermore, the $\delta^{2} \mathrm{H} \quad(-67 \%)$ and $\delta^{18} \mathrm{O}(-8.1 \%)$ values of formation water are much lower than those of salt lakes (Fig. 4b). These reflect that the possibility of formation water recharged by salt lake water through deep fault can be excluded.

$\mathrm{The} \mathrm{Cl} / \mathrm{Br}$ of formation water is higher than that of seawater (657.89). Conversely, the $\mathrm{Cl}$ concentration of formation water $(164.62 \mathrm{mM})$ is lower than that of seawater $(535.21 \mathrm{mM})$ (Fig. 4a). These indicate that the source of formation water may be ancient seawater, which is further modified by dilution and halite dissolution resulting in increased $\mathrm{Cl} / \mathrm{Br}$ and decreased $\mathrm{Cl}$ concentration as shown in Fig. 4a. However, the low $\mathrm{SO}_{4} /\left(\mathrm{Cl}+\mathrm{SO}_{4}\right)$ moral ratio $\left(3.078 \times 10^{-3}\right)$ reflects that the formation water trapped in the continental shale of the Dameigou Formation was in a closed environment [25].
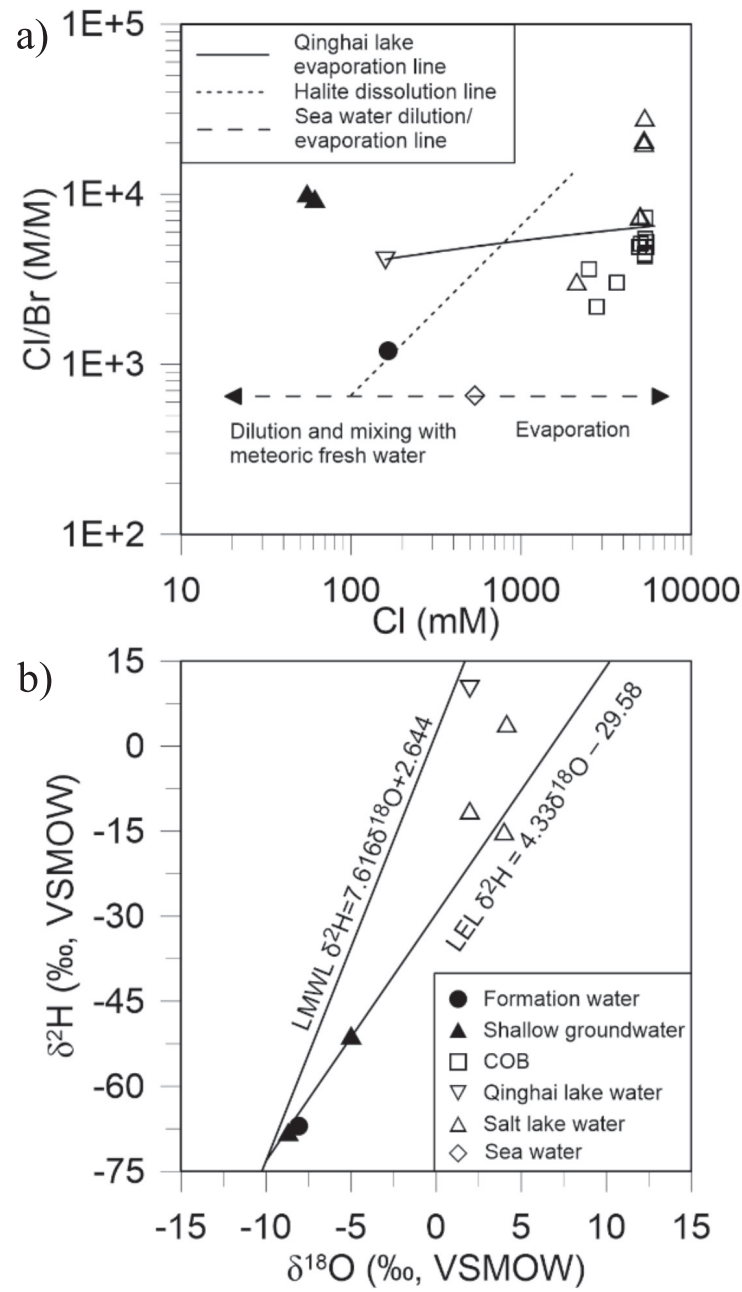

Fig. 4. a) Plot of $\mathrm{Cl} / \mathrm{Br}$ moral ratio versus $\mathrm{Cl}$ moral concentration in the formation water of Dameigou Shale, salt lake water, seawater, $\mathrm{COB}$, and shallow groundwater; evaporation curve of Qinghai Lake water, evaporation and dilution line of seawater, dissolution line of halite are also plotted; b) plot of $\delta^{2} \mathrm{H}$ versus $\delta^{18} \mathrm{O}$ in the formation water of Dameigou Shale, seawater, salt lake water, and shallow groundwater; also plotted are the local meteoric water line (LMWL) and local evaporation line (LEL).

In addition, the Dameigou Formation contains no halite or sylvite (Fig. 2). Thus, the possibility of formation water originating from ancient seawater can be ruled out.

The low permeability of shale $\left(<0.05 \times 10^{-3} \mu \mathrm{m}^{2}\right)$ [21] and closed environment indicate that the formation water was trapped in the shale when the shale formation was deposited. A previous study reported that the Dameigou Formation was deposited in a semi-deep lake environment [20]. In addition, the formation water is plotted close to the local evaporation line (LEL) [26] in the $\delta^{2} \mathrm{H}-\delta^{18} \mathrm{O}$ plot (Fig. 4b). This suggests that the formation water is supposed to have originated from evaporated ancient lake water, which was mainly recharged by rainwater in the Middle Jurassic period. 
Table 2. Comparison of major ion compositions in measured formation water and calculated formation water; the major ion compositions in calculated formation water are determined from evaporated rainwater (367-fold) and geochemical processes.

\begin{tabular}{|c|c|c|c|c|c|c|c|c|}
\hline Ions & $\begin{array}{c}\text { Rain water } \\
(\mathrm{mg} / \mathrm{L})\end{array}$ & $\begin{array}{c}\text { Evaporated rainwater } \\
(367-f o l d)(\mathrm{mM})\end{array}$ & $\begin{array}{c}\Delta C_{\text {TSR }} \\
(\mathrm{mM})\end{array}$ & $\begin{array}{c}\Delta C_{\text {kaolinization }} \\
(\mathrm{mM})\end{array}$ & $\begin{array}{c}\Delta C_{\text {Dolomitization }} \\
(\mathrm{mM})\end{array}$ & $\begin{array}{c}\Delta C_{\text {Calcitization }} \\
(\mathrm{mM})\end{array}$ & $\begin{array}{c}\text { Calculated FW } \\
(\mathrm{mM})\end{array}$ & $\begin{array}{c}\text { Measured FW } \\
(\mathrm{mM})\end{array}$ \\
\hline $\mathrm{Na}$ & 9.64 & 153.90 & $/$ & 32.36 & $/$ & $/$ & 186.26 & 186.26 \\
\hline $\mathrm{K}$ & 1.01 & 9.39 & $/$ & 0.23 & $/$ & $/$ & 9.62 & 9.62 \\
\hline $\mathrm{Ca}$ & 15.30 & 80.47 & -26.13 & $/$ & 27.14 & -79.84 & 1.63 & 1.63 \\
\hline $\mathrm{Mg}$ & 3.76 & 29.69 & $/$ & $/$ & -27.14 & $/$ & 2.55 & 2.55 \\
\hline $\mathrm{Cl}$ & 15.02 & 155.50 & $/$ & $/$ & $/$ & $/$ & 155.50 & 164.62 \\
\hline $\mathrm{HCO}_{3}$ & 46.39 & 162.60 & $/$ & 32.59 & $/$ & -159.68 & 35.52 & 39.13 \\
\hline $\mathrm{SO}_{4}$ & 14.96 & 26.38 & -26.13 & $/$ & $/$ & $/$ & 0.25 & 0.25 \\
\hline
\end{tabular}

a)
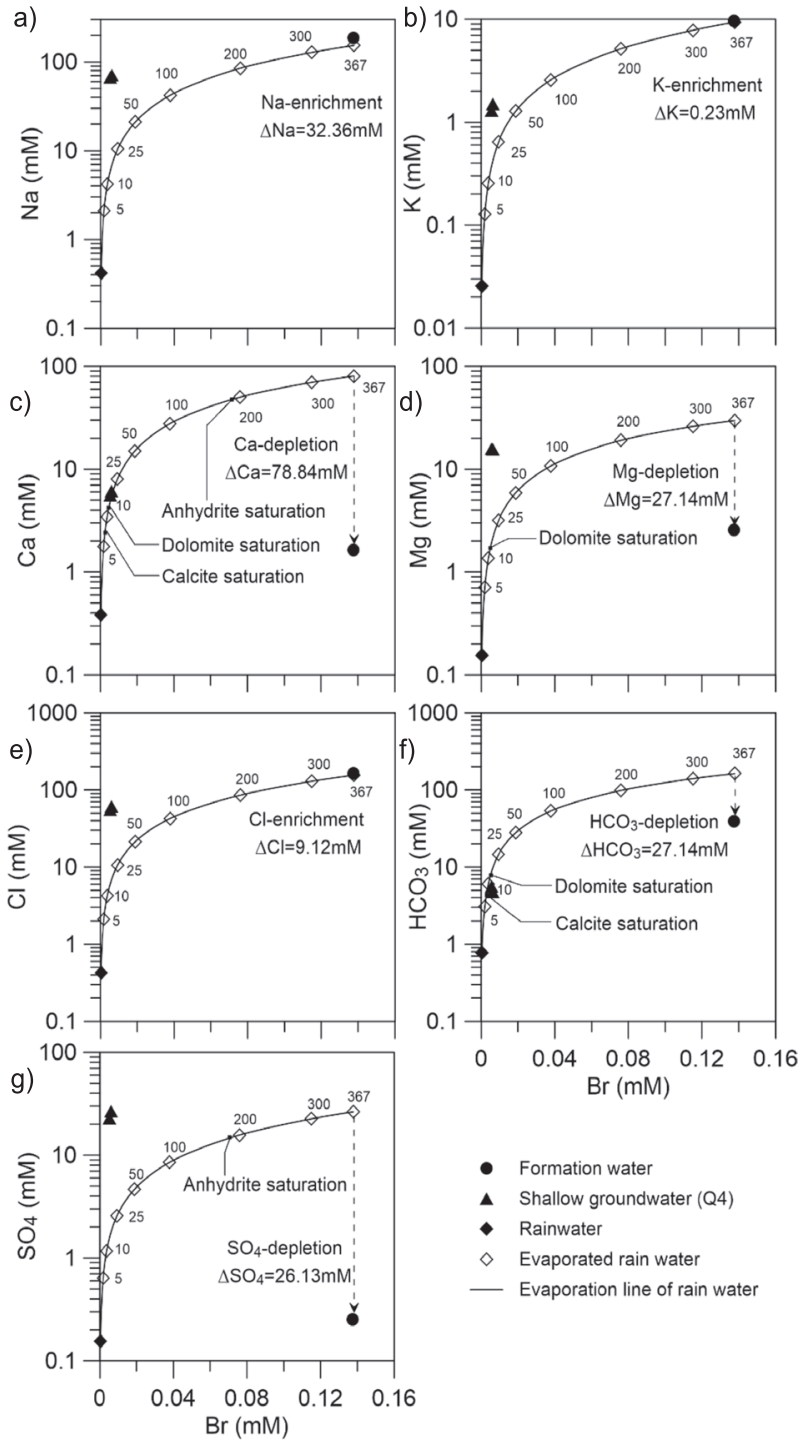

- Formation water

- Shallow groundwater (Q4)

- Rainwater

Evaporated rain water

- Evaporation line of rain water

Fig. 5. a) $\mathrm{Na}$, b) $\mathrm{K}$, c) $\mathrm{Ca}$, d) $\mathrm{Mg}$, e) $\mathrm{Cl}$, f) $\mathrm{HCO}_{3}$ and g) $\mathrm{SO}_{4}$ versus their respective $\mathrm{Br}$ concentrations for the formation water, shallow groundwater and 5-367 fold evaporated rainwater; also plotted are the evaporation line of rain water and saturation point of phase. The evaporated rain water and saturation point of phase were modeled by PHREEQC. Enrichment/depletion of main ion of the Dameigou formation water in comparison to the 367 -fold evaporated rain water are also shown in plots.

Geochemical Evolution of Formation Water

\section{Evaporation}

Natural crystalline bromide minerals are very rare in sedimentary strata [27]. Thus, bromine occurrence in rock-forming minerals is most commonly associated with substitutions of $\mathrm{Cl}$ for $\mathrm{Br}$ in chlorine-rich minerals such as halite, sodalite and eudialyte because of the similar ionic radii of the two ions $(\mathrm{Cl}: 181 \mathrm{pm}$, Br: 196 pm) [28]. However, no chlorine-rich minerals have been found in the Dameigou Formation. Furthermore, in the water-rock interactive system, bromide dose does not participate in the geochemical process as a conservative constituent. This suggests that the concentration of $\mathrm{Br}$ in formation water is only controlled by the origin of formation water and evaporation. Distinctive $\mathrm{Br}$ concentration (11.00 mg/L) in formation water suggests a 367 -fold evaporation of the rainwater $(0.03 \mathrm{mg} / \mathrm{L})$ beyond saturation stages of calcite, dolomite, and anhydrite (Table 2, Fig. 5).

The evaporation modeling of rainwater is established for the purpose of discussing the geochemical processes, not accounting for evaporation during the process of creating formation water, which would highly affect the hydrogeochemical compositions. The PHREEQC simulations show that the simulated $(5520.3 \mathrm{mg} / \mathrm{L})$ and measured $(5844.1 \mathrm{mg} / \mathrm{L})$ concentrations of $\mathrm{Cl}$ are almost consistent with the relative error less than $5 \%$, which supports the evaporation-fold calculation using $\mathrm{Br}$ in the no Cl-bearing Dameigou Formation. The significant depletion of $\mathrm{SO}_{4}, \mathrm{Ca}, \mathrm{Mg}$, and $\mathrm{HCO}_{3}$ and enrichment of $\mathrm{Na}$ and $\mathrm{K}$ of measured formation water in comparison to simulated results (Table 2, Fig. 5) indicate that the evaporated fresh lake water was further modified by geochemical processes.

\section{Thermochemical Sulfate Reduction (TSR)}

The concentration of $\mathrm{SO}_{4}$ in formation water is only $24 \mathrm{mg} / \mathrm{L}$ showing a significant depletion $\left(\Delta \mathrm{SO}_{4}=26.13 \mathrm{mM}\right)$ (Fig. $\left.5 \mathrm{~g}\right)$. In addition, the evaporation modeling of rainwater show that anhydrite 

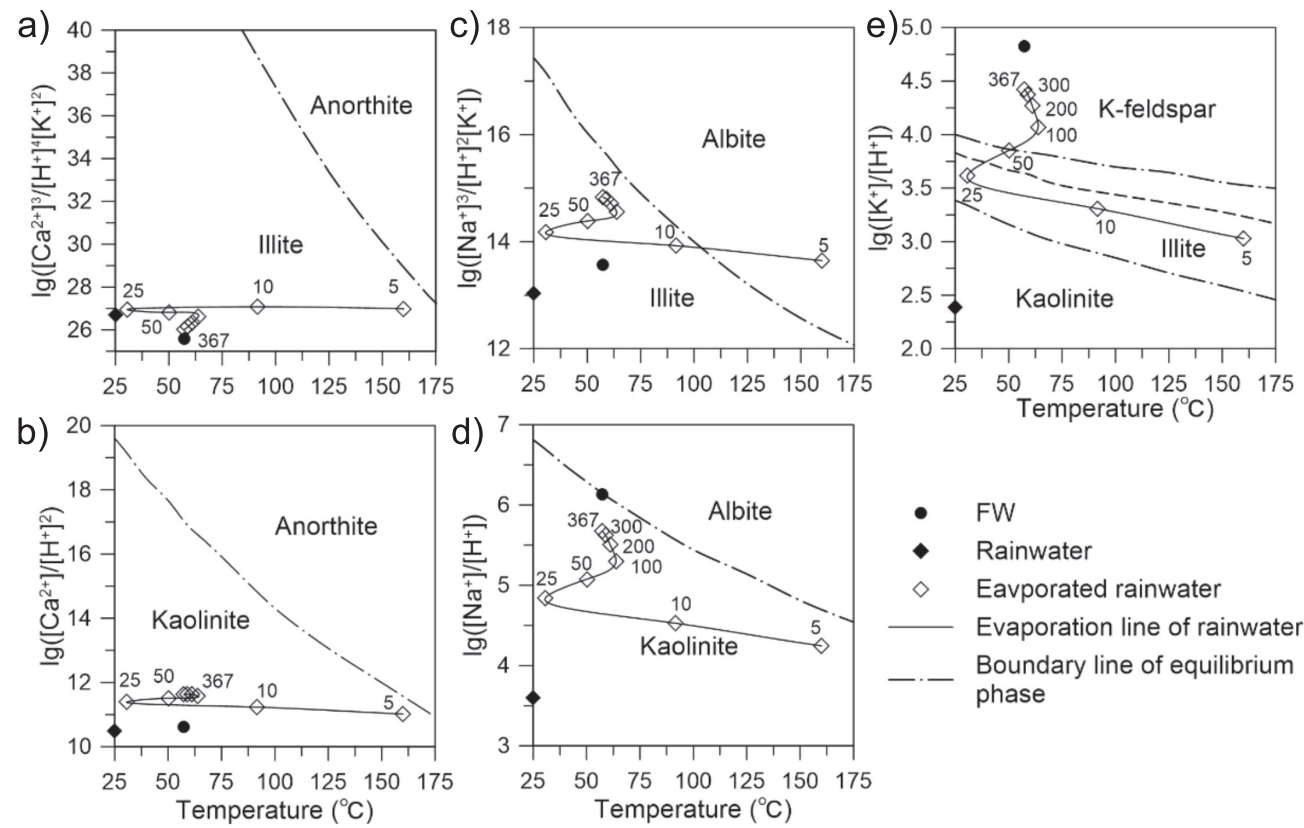

Fig. 6. Mineral stability diagrams in systems of a) anorthite-illite, b) anorthite-kaolinite, c) albite-illite, d) albite-kaolinite, and e) k-feldspar-illite-kaolinite [35] for the formation water, rainwater and the evaporated rainwater at their respective temperatures and 0.1 MP. The dotted line in e) indicates the equilibrium phase boundary of the k-feldspar dissolution to kaolinite. Huang et al. reported that temperature influences the feldspar dissolution equilibrium in all systems, but pressure does not [36], thus the equilibrium phase boundary plotted at $0.1 \mathrm{MP}$ can be acceptable in this study.

was precipitated from liquid phase when the evaporation reached about 200-fold. However, the formation water (367-fold evaporated rainwater) is unsaturated for anhydrite and no anhydrites have been found in the shale formation. This suggests that the depleted $\mathrm{SO}_{4}$ in formation water were not transferred from liquid phase to solid phase by precipitation, but resulted from the insitu sulfate reduction. Thermochemical sulfate reduction (TSR) and bacterial sulfate reduction (BSR) are the two main desulfidation processes and form similar products and by-products [29-30]. However, the two processes take place in two mutually exclusive thermal regimes, which is the most important factor governing the involved redox-reactions [31]. Previous studies reported that BSR and TSR occur in geological settings with temperatures of $0-80^{\circ} \mathrm{C}$ which correspond to vitrinite reflectance values of about $0.2-0.3 \%$ and $120-200^{\circ} \mathrm{C}$, which correspond to vitrinite reflectance values of about $1.0-4.0 \%$, respectively [31]. In addition, the closed system is considered as a specific limit to BSR, because the associated increase in $\mathrm{H}_{2} \mathrm{~S}$ concentrations are toxic to sulfate-reducing bacteria [32]. Hence, the temperature $\left(>120{ }^{\circ} \mathrm{C}\right)$ of the Dameigou Formation from $150 \mathrm{Ma}$ to $120 \mathrm{Ma}$, the vitrinite reflectance values $(1.0-1.3 \%)$ of shale, and the closed environment of the formation water indicate that TSR was the main desulphidation according to above discriminating criteria, and resulted in secondary calcite, $\mathrm{CO}_{2}$ and $\mathrm{H}_{2} \mathrm{~S}$ as described in equation 1 [33-34].

The $\delta^{34} \mathrm{~S}-\mathrm{H}_{2} \mathrm{~S}$ value formed by TSR is very close to that of sulfate in the formation. Thus, the $\delta^{34} \mathrm{~S}-\mathrm{H}_{2} \mathrm{~S}$ value in formation water $(25.9 \%$ ), which was highly altered by TSR, is distinguished from that in shallow groundwater $(6.2-8.6 \%)$. This suggests that $\delta^{34} \mathrm{~S}-\mathrm{H}_{2} \mathrm{~S}$ can be a promising tracer of HFFF.

$$
2 \mathrm{C}+\mathrm{Ca}^{2+}+\mathrm{SO}_{4}^{2-}+\mathrm{H}_{2} \mathrm{O} \rightarrow \mathrm{CaCO}_{3}+\mathrm{H}_{2} \mathrm{~S}+\mathrm{CO}_{2}
$$

\section{Kaolinization and Illitization of Feldspar}

The formation water has $\mathrm{Na}$ and $\mathrm{K}$ concentrations of approximately $186.26 \mathrm{mM}$ and $9.62 \mathrm{mM}$, which is an enrichment of $32.36 \mathrm{mM}$ and $0.23 \mathrm{mM}$ relative to 367-fold evaporated rainwater (153.90 $\mathrm{mM}$ and 9.39 $\mathrm{mM})$, respectively. The Dameigou Formation contains neither halite nor sylvite, reflecting the fact that dissolution of plagioclase feldspar and K-feldspar by carbonic acid produced by TSR is a potential source of enriched $\mathrm{Na}$ and $\mathrm{K}$ in formation water. The mineral stability diagrams (Fig. 6) show that plagioclase feldspar is weathered to illite or kaolinite during most of the formation water's hydrochemical evolution history. Conversely, K-feldspar dissolved incongruently only in the early stages of hydrochemical evolution (original rainwater to 5-fold evaporated rainwater). These results show that feldspar dissolution leads to the considerable enrichment of $\mathrm{Na}$ and slight enrichment of $\mathrm{K}$ in formation water. Yuan et al. reported that $\mathrm{K}$ in the fluid makes the Gibbs free energy change $(\Delta G)$ of feldspar illitization less than that of feldspar kaolinization [36]. Thus, from the perspective of thermodynamics, illite 
would be preferentially precipitated. However, the influence of the kinetic barrier of nucleation results in diagenetic illite by feldspar dissolution occurring in formations at temperatures above $120^{\circ} \mathrm{C}$ [37]. Shao et al. studied the thermal history of the Middle Jurassic strata in the northern Qaidam Basin using apatite fission track dating and found that the formation temperature dropped rapidly from $120^{\circ} \mathrm{C}$ since 100-120 Ma due to the rapid compressional uplift of the strata, then remained at between $30^{\circ} \mathrm{C}$ and $60^{\circ} \mathrm{C}$ [22]. In addition, the dissolution of $\mathrm{K}$-feldspar only occurred in the early stages of hydrochemical evolution. If the illitization of plagioclase felspar occurred during the entire hydrochemical evolution period, $\mathrm{K}$ in formation water should be depleted relative to 367 -fold evaporated rainwater, which is inconsistent with the data. All of these factors suggest that kaolinization of plagioclase feldspar and K-feldspar (Equation 2 to 4) resulted in the enrichment of $\mathrm{Na}$ and $\mathrm{K}$ in formation water [38].

Feldspar is the principal $\mathrm{Sr}$ carrier in shale. Feldspar in the Dameigou Formation is characterized by a high ${ }^{87} \mathrm{Sr} /{ }^{86} \mathrm{Sr}$ value (0.720) [3]. The ${ }^{87} \mathrm{Sr} /{ }^{86} \mathrm{Sr}$ ratio in formation water is highly influenced by the type of host rock through water-rock interactions [39]. Thus, the high ${ }^{87} \mathrm{Sr} /{ }^{86} \mathrm{Sr}$ value of the formation water $(0.713842)$ relative to rainwater $(0.706-0.709)$, which is the source of the formation water, suggests that dissolution of feldspar dominates the $\mathrm{Sr}$ isotope characteristics of formation water. The conventional oil reservoirs are composed of limestone, which are characterized by low ${ }^{87} \mathrm{Sr} /{ }^{86} \mathrm{Sr}$ values $(<0.709)$ [40]. The interaction between limestone and $\mathrm{COB}$ led to lowering ${ }^{87} \mathrm{Sr} /{ }^{86} \mathrm{Sr}$ values (0.71121-0.71194) in the COB. Therefore, the ${ }^{87} \mathrm{Sr} /{ }^{86} \mathrm{Sr}$ ratio, which is distinct from that of $\mathrm{COB}$ and shallow groundwater $(0.712140-0.712273)$, can be a potential tracer of HFFF

$$
\begin{gathered}
2 \mathrm{KAlSi}_{3} \mathrm{O}_{8}(\mathrm{~K} \text {-feldspar })+2 \mathrm{H}_{2} \mathrm{CO}_{3}+\mathrm{H}_{2} \mathrm{O} \\
=\mathrm{Al}_{2} \mathrm{Si}_{2} \mathrm{O}_{5}(\mathrm{OH})_{4}(\mathrm{Kaolinite})+4 \mathrm{SiO}_{2}+2 \mathrm{~K}^{+}+2 \mathrm{HCO}_{3}^{-}
\end{gathered}
$$

$$
\begin{gathered}
2 \mathrm{NaAlSi}_{3} \mathrm{O}_{8} \text { (Albite) }+2 \mathrm{H}_{2} \mathrm{CO}_{3}+\mathrm{H}_{2} \mathrm{O} \\
=\mathrm{Al}_{2} \mathrm{Si}_{2} \mathrm{O}_{5}(\mathrm{OH})_{4}(\text { Kaolinite })+4 \mathrm{SiO}_{2}+2 \mathrm{Na}^{+}+2 \mathrm{HCO}_{3}^{-}
\end{gathered}
$$

$$
\begin{aligned}
& \mathrm{CaAl}_{2} \mathrm{Si}_{2} \mathrm{O}_{8} \text { (Anorthite) }+2 \mathrm{H}_{2} \mathrm{CO}_{3}+\mathrm{H}_{2} \mathrm{O} \\
= & \mathrm{Al}_{2} \mathrm{Si}_{2} \mathrm{O}_{5}(\mathrm{OH})_{4} \text { (Kaolinite) }+\mathrm{Ca}^{2+}+2 \mathrm{HCO}_{3}^{-}
\end{aligned}
$$

\section{Dolomitization and Calcitization}

The formation water has an $\mathrm{Mg}$ concentration of approximately $2.55 \mathrm{mM}$, which is a $27.14 \mathrm{mM}$ depletion relative to 367 -fold evaporated rainwater $(29.69 \mathrm{mM})$ obtained by simulation. Dolomitization of carbonates is considered to be the main mechanism for $\mathrm{Mg}$ depletion, coupled with $\mathrm{Ca}$ enrichment (Equation 5), which is widely reported in many basins [41]. The formation of secondary calcite increased the $\mathrm{Mg} / \mathrm{Ca}$ ratio through TSR and evaporation, and promoted dolomitization. The decrease of calcite and the increase of Ca caused by dolomitization in turn promoted the TSR reaction until $\mathrm{SO}_{4}$ in the formation water was exhausted. Assuming that dolomitization is the only process accounting for the depletion of $\mathrm{Mg}$ in the formation water, a $27.14 \mathrm{mM} \mathrm{Ca}$ enrichment is expected from dolomitization. In addition, a $26.13 \mathrm{mM}$ Ca depletion is calculated from $\mathrm{SO}_{4}$ depletion during the TSR reaction. Hence, other geochemical processes must have precipitated or adsorbed $\mathrm{Ca}$ in the formation water, leading to the $\mathrm{Ca}$ depletion of up to $78.84 \mathrm{mM}$ (Table 2).

The plagioclase feldspar in Dameigou Formation contain little anorthite. Thus, replacing plagioclase feldspar with albite is acceptable in this study for calculating phase mole transfer (the moles of minerals that must enter or leave a solution by geochemical processes). Kaolinizations of albite and K-feldspar by carbonic acid resulted in a $32.59 \mathrm{mM}$ enrichment of $\mathrm{HCO}_{3}$. This means that additional $\mathrm{HCO}_{3}$ has precipitated through other geochemical processes, giving rise to $\mathrm{HCO}_{3}$ depletion of up to $123.47 \mathrm{mM}$ in the formation water. The ratio of $\mathrm{Ca}(79.84 \mathrm{mM})$ and $\mathrm{HCO}_{3}$ $(156.07 \mathrm{mM})$ to be precipitated/adsorbed is almost $1: 2$, and the formation water was saturated relative to calcite since the early stages of its hydrochemical evolution (Table 2). This indicates that the $\mathrm{Ca}$ and $\mathrm{HCO}_{3}$ in formation water were most probably depleted by calcite precipitation (Equation 6).

Barium is an alkaline earth element, chemically similar to Calcium [38]. Thus, the Ba can substitute for $\mathrm{Ca}$ during calcitization [42]. Due to strong adsorption by clay minerals, shale is abundant in exchangeable $\mathrm{Ba}$ (average value of $580 \mathrm{ppm}$ ) relative to sandstones (average value of $10 \mathrm{ppm}$ ) [43]. In addition, all evaporated rainwater simulated by PHREEQC showed positive ratios for CA index, a formula to determine the ion exchange between groundwater and its aquifer during residences [44], suggesting that $\mathrm{Na}$ in the water exchanged with $\mathrm{Ba}$ adsorbed previously on the surface of clay minerals in the shale formation. Thus, the $\mathrm{Ba}$ in shale formation water could be distinct from shallow groundwater hosted by sandstone formation. The Ba concentration of the formation water $(5.79 \mathrm{mg} / \mathrm{L})$ is higher than that of shallow groundwater $(<0.02 \mathrm{mg} / \mathrm{L})$, which suggests that $\mathrm{Ba}$ incorporated in $\mathrm{CaCO}_{3}$ by calcitization did not decrease the $\mathrm{Ba}$ concentration in formation water to a similar range for shallow groundwater. Hence, the ratio $\left(2.60 \times 10^{-2}\right)$ of considerably enriched $\mathrm{Ba}$ and significantly depleted $\mathrm{Ca}$ in formation water is supposed to be much higher than that in shallow groundwater $\left(2.03 \times 10^{-5}-2.25 \times 10^{-5}\right)$, and can be used as a tracer of HFFF.

$$
\begin{gathered}
\mathrm{CaCO}_{3}+\mathrm{Mg}^{2+} \rightarrow \mathrm{CaMg}\left(\mathrm{CO}_{3}\right)_{2}+\mathrm{Ca}^{2+} \\
\mathrm{Ca}^{2+}+2 \mathrm{HCO}_{3}^{-} \rightarrow \mathrm{CaCO}_{3}+2 \mathrm{H}_{2} \mathrm{O}
\end{gathered}
$$




\section{Dissolution of Borate}

The $\delta^{11} \mathrm{~B}$ of the formation water $(1.1 \%)$ is much higher than that of rainwater (16.7\%) [45] (the source of the formation water), indicating that geochemical processes have depleted the $\delta^{11} \mathrm{~B}$ in formation water, because evaporation cause little $\mathrm{B}$ isotope fractionation [46]. Nir et al. found that the $\delta^{11} \mathrm{~B}$ value in the aqueous phase $(\mathrm{pH}>6.7)$ increased as a result of the preferential adsorption of ${ }^{10} \mathrm{~B}(\mathrm{OH})_{4}^{-}$on clay minerals in a closed water-rock interactive system [47]. Thus, preferential adsorption could not be the major factor affecting $B$ isotope in the Dameigou Formation. A series of calcite precipitation experiments have shown that $\mathrm{B}(\mathrm{OH})_{4}^{-}$is the dominant species incorporated into calcite, which leads to an increase of $\delta^{11} \mathrm{~B}$ value in the aqueous phase [48]. This reflects on how calcitization cannot be the major geochemical process controlling the boron isotope in formation water. Boron in the crust is present mainly in the form of borate. The $\delta^{11} \mathrm{~B}$ values of borate minerals in non-marine strata range from $-30.1 \%$ o to $10.2 \%$, with an average of $4 \%$ [49] and the $\delta^{11} \mathrm{~B}$ of formation water $(1.1 \%$ ) from Dameigou Shale is similar to that of brines $(\sim 0 \%)$ in non-marine strata [50]. This suggests that dissolution of borates is dominated by the $\mathrm{B}$ isotope during the geochemical evolution of formation water.

The $\mathrm{COB}$, which is originated from rainwater the same as formation water, have higher $\delta^{11} \mathrm{~B}$ values $(12-31 \%$ ) than that of the formation water. $\mathrm{Li}$ et al. reported that $\mathrm{COB}$ recharged from rainwater and evolved by the geochemical processes such as leaching and adsorption with surrounding rock and mixing with mantle source of thermal water during hydrologic circulation through deep faults [51]. The $\delta^{11} \mathrm{~B}$ value (12-31\%) of COB approximate the rainwater (16.7\%o) indicates that the water-rock interaction and mixing did not considerably affect the $\delta^{11} \mathrm{~B}$ value. The $\delta^{11} \mathrm{~B}$ values of shallow groundwater (24-26\%) which were mainly modified by preferential adsorption after recharging from rainwater, are also distinguishable from formation water. Therefore, the $\delta^{11} \mathrm{~B}$ of the formation water, which is controlled by a distinctive geochemical process, can be used as a tracer of HFFF.

\section{Conclusions}

(1) The hydrochemistry $\left(\mathrm{SO}_{4} /\left(\mathrm{Cl}+\mathrm{SO}_{4}\right)\right.$, and $\mathrm{Br} /$ $\mathrm{Cl})$ and isotopic compositions $\left(\delta^{2} \mathrm{H}\right.$ and $\left.\delta^{18} \mathrm{O}\right)$ of the formation water, mineralogical composition of the shale, fossil records in the shale, and sedimentary environment of the shale suggest that the formation water originated from evaporated rainwater.

(2) The major geochemical processes that dominate evolution of the geochemistry of the formation water were TSR, kaolinization of plagioclase feldspar, dolomitization, calcitization and borate dissolution, leading to significant enrichment in $\mathrm{Na}$ and considerable depletion in $\mathrm{Ca}, \mathrm{Mg}, \mathrm{SO}_{4}$ and $\mathrm{HCO}_{3}$.
(3) The leading geochemical processes have given the formation water a distinctive $\mathrm{Br} / \mathrm{Cl}, \mathrm{Ba} / \mathrm{Ca}, \delta^{34} \mathrm{~S}$ $\mathrm{H}_{2} \mathrm{~S},{ }^{87} \mathrm{Sr} /{ }^{86} \mathrm{Sr}$ and $\delta^{11} \mathrm{~B}$ compared with $\mathrm{COB}$ in shallow groundwater. These diagnostic tracers can be used in forensic identification of HFFF release into shallow groundwater.

\section{Acknowledgements}

We gratefully acknowledge funding from the National Natural Science Foundation of China (Grant No. 41302192), the Natural Science Foundation of Hebei Province of China (Grant No. D2018504011), the Chinese Academy of Geological Sciences (Grant No. JYYWF20181101), and the Ministry of land and resources of the People's Republic of China (Grant No. 201411052).

\section{Conflict of Interest}

The authors declare no conflict of interest.

\section{References}

1. BRITISH PETROLEUM. BP statistical review of world energy, London 2018. Available online: https://www. bp.com/content/dam/bp/business-sites/en/global/corporate/ pdfs/energy-economics/statistical-review/bp-stats-review2018-full-report.pdf

2. WOOD MACKENZIE. Can China deliver a shale gas boom by 2020 ? Edinburgh 2018.

3. ZHENG Z., ZHANG H., CHEN Z., LI X., ZHU P., CUI $X$. Hydrogeochemical and isotopic indicators of hydraulic fracturing flowback fluids in shallow groundwater and stream water, derived from Dameigou shale gas extraction in the Northern Qaidam Basin. Environ. Sci. Technol. 51 (11), 5889, 2017.

4. VENGOSH A., JACKSON R.B., WARNER, N.R., DARRAH T., KONDASH A. A critical review of the risks to water resources from unconventional shale gas development and hydraulic fracturing in the United States. Environ. Sci. Technol. 48 (15), 8334, 2014.

5. OSBORN S.G., VENGOSH A., WARNER N.R., JACKSON R.B. Methane contamination of drinking water accompanying gas-well drilling and hydraulic fracturing. Proc. Natl. Acad. Sci. 108 (20), 8172, 2011.

6. WARNER N.R., JACKSON R.B., DARRAH T.H., OSBORN S.G., DOWN A., ZHAO K., WHITE A., VENGOSH A. Geochemical evidence for possible natural migration of Marcellus formation brine to shallow aquifers in Pennsylvania. Proc. Natl. Acad. Sci. 109 (30), 11961, 2012.

7. KAHRILAS G.A., BLOTEVOGEL J., STEWART P.S., BORCH T. Biocides in hydraulic fracturing fluids: A critical review of their usage, mobility, degradation, and toxicity. Environ. Sci. Technol. 49, 16, 2015.

8. STELIGA T., KLUK D., JAKUBOWICZ P. Analysis of chemical and toxicological properties of fluids for shale hydraulic fracturing and flowback water. Pol. J. Environ. Stud. 24 (5), 2185, 2015. 
9. BUTKOVSKYI A., BRUNING H., KOOLS S., RIJNAARTS H., VAN WEZEL A.P. Organic pollutants in shale gas flowback and produced waters: Identification, potential ecological impact, and implications for treatment strategies. Environ. Sci. Technol. 51 (9), 4740, 2017.

10. OSBORN S.G., MCINTOSH J.C. Chemical and isotopic tracers of the contribution of microbial gas in Devonian organic-rich shales and reservoir sandstones, northern Appalachian Basin. App. Geochem. 25 (3), 456, 2010.

11. MCLNTOSH J., HENDRY M.J., BALLENTINE C.J., HASZELDINE R.S., MAYER B., ETIOPE G., ELSNER M., DARRAH T.H., PRINZHOFER A., OSBORN S., STALKER L., KULOYO O., LU Z., MARTINI A., LOLLAR B.S. A critical review of state-of-the-art and emerging approaches to identify fracking-derived gases and associated contaminants in aquifers. Environ. Sci. Technol. 53 (3), 1063, 2019.

12. WARNER N.R., DARRAH T.H., JACKSON R.B., MILLOT R., KLOPPMANN W., VENGOSH A. New tracers identify hydraulic fracturing fluids and accidental releases from oil and gas operations. Environ. Sci. Technol. 48 (21), 12552, 2014

13. VENGOSH A., WARNER N.R., KONDASH A., JENIFER S.H., LAUER N., MILLOT R., KLOPPMAN W., DARRAH T.H. Isotopic fingerprints for delineating the environmental effects of hydraulic fracturing fluids. Procedia Earth and Planetary Science. 13, 244, 2015.

14. CHAPMAN E.C., CAPO R.C., STEWART B.W., KIRBY C.S., HAMMACK R.W., SCHROEDER K.T., EDENBORN H.M. Geochemical and strontium isotope characterization of produced waters from Marcellus Shale natural gas extraction. Environ. Sci. Technol. 46 (6), 3545, 2012.

15. U.S. EIA. International energy data and analysis - China. U.S. EIA, Washington 2015, D.C. Available online: https://www.eia.gov/beta/international/analysis_includes/ countries long/China/china.pdf

16. LI J., LI T., MA H., PENG X. Investigation of the chemical characteristics and its geological significance of the Tertiary oilfield brine in the western Qaidam Basin. Hydrology \& Engineering Geology, 40 (6), 28, 2013 [In Chinese].

17. PICHTEL J. Oil and gas production wastewater: soil contamination and pollution prevention. Appl. Environ. Soil. Sci. 2016, 1, 2016.

18. WANG $\mathrm{X}$. Shale gas reservoir conditions analysis of Middle Jurassic in the Northern Qaidam Basin. Dissertation, Chang'an University, 2015 [In Chinese].

19. TANG Y., ZHANG Y., LI Y. The potential evaluation of shale oil in the seventh member of Dameigou Formation $\left(\mathrm{J}_{2} \mathrm{~d}^{7}\right)$ on the northern margin of Qaidam Basin: A case study of Dameigou area. Geology in China. 43 (2), 575, 2016 [In Chinese].

20. KANG Z., ZHOU L., REN S., KONG J., CHEN Y. Characteristic of shale of the $7^{\text {th }}$ member of the Middle Jurassic Dameigou Formation in Northern Qaidam Basin. Earth Science Frontiers. 22 (4), 256, 2015 [In Chinese].

21. LI H., REN S., GUO T., WANG S., ZHOU Z., XU Q. Organic geochemistry characteristics and reservoir conditions of Jurassic shale in Yuqia depression of northern Qaidam Basin: A case study of Chaiye- 1 well. Geo Bull China. 35 (2/3), 250, 2016 [In Chinese].

22. SHAO Y., YAN D., ZHAO X., LIU W., SHI Q., LIU L., SUN Q. Mesozoic-Cenozoic thermal evolution and its significance to sandstone type uranium mineralization in the Northern margin of Qaidam Basin. Uranium Geology. 32 (5), 287, 2016 [In Chinese].

23. LI T. The origin analysis by hydro-chemical characters and $\mathrm{Sr}$ isotope of oil field brines in west of Qaidam Basin. Dissertation, Institute of Salt Lakes, Chinese Academy of Sciences, 2007 [In Chinese].

24. BIRKLE P. Geochemical fingerprinting of hydraulic fracturing fluids from Qusaiba Hot Shale and formation water from Paleozoic petroleum systems, Saudi Arabia. Geofluids. 16, 565, 2016.

25. LI J., WANG B., SHAO L., ZHAO Y., CAO H., WANG Z., ZHANG W. Hydrogeological zoning and its gascontrolling mechanism: A case study of Baode block, eastern Ordos gas field. Journal of China University of Mining \& Technology. 46 (4), 869, 2017 [In Chinese].

26. ZHU P. Groundwater circulation patterns of Yuqia-Mahai Basin in the middle and lower reaches of Yuqia River. Dissertation, Jilin University, 2015 [In Chinese].

27. CHEN C., APUL O.G., KARANFIL T. Removal of bromide from surface waters using silver impregnated activated carbon. Water Research. 113, 223, 2017

28. PAGE L., HATTORI K., HOOG J.C.M, OKAY A.I. Halogen $(\mathrm{F}, \mathrm{Cl}, \mathrm{Br}, \mathrm{I})$ behaviour in subducting slabs: $\mathrm{A}$ study of lawsonite blueschists in western Turkey. Earth and Planetary Science Letters. 442, 133, 2016.

29. FU Y., BERK W.V., SCHULZ H. Hydrogen sulfide formation, fate, and behavior in anhydrite-sealed carbonate gas reservoirs: A three-dimensional reactive mass transport modeling approach. AAPG Bulletin. 11 (5), 843,2016

30. LI X., LAN S., ZHU Z., ZHANG C., ZENG G., LIU Y., CAO W., SONG B., YANG H., WANG S., WU S. The bioenergetics mechanisms and applications of sulfatereducing bacteria in remediation of pollutants in drainage: A review. Ecotoxicology and Environmental Safety. 158, 162,2018

31. JIA L., CAI C., YANG H., LI H., WANG T., ZHANG B., JIANG L., TAO X. Thermochemical and bacterial sulfate reduction in the Cambrian and Lower Ordovician carbonates in the Tazhong Area, Tarim Basin, NW China: evidence from fluid inclusions, $\mathrm{C}, \mathrm{S}$, and $\mathrm{Sr}$ isotopic data. Geofluids. 15, 421, 2015.

32. KUSHKEVYCH I., DORDEVIC D., VITEZOVA M. Toxicity of hydrogen sulfide toward sulfate-reducing bacteria Desulfovibrio piger Vib-7. Archives of Microbiology. 201 (3), 389, 2019.

33. CAI C., TANG Y., LI K., JIANG K., JIANG C., XIAO Q. Relative reactivity of saturated hydrocarbons during thermochemical sulfate reduction. Fuel. 253, 106, 2019.

34. LI K., CAI C., JIA L., CAO Y., JIANG Z., WANG T., JIANG L. The role of thermochemical sulfate reduction in the genesis of high-quality deep marine reservoirs within the central Tarim Basin, western China. Arab J Geosci. 8 (7), 4443, 2014

35. WEI W., HUANG S., XUN J. Thermodynamic calculation of illite formation and its significance on research of sandstone diagenesis. Geological Science and Technology Information. 30 (1), 20, 2011 [In Chinese].

36. YUAN G., CAO Y., SCHULZ H.M., HAO F., GLUYAS J., LIU K., YANG T., WANG Y., XI K., LI F. A review of feldspar alteration and its geological significance in sedimentary basins: From shallow aquifers to deep hydrocarbon reservoirs. Earth-Science Review. 191, 114, 2019.

37. YUAN G., CAO Y., GLUYAS J., LI X., XI K., WANG Y., JIA Z., SUN P., OXTOBY N.H. Feldspar dissolution, 
authigenic clays, and quartz cements in open and closed sandstone geochemical systems during diagenesis: Typical examples from two sags in Bohai Bay Basin, East China. AAPG Bulletin. 99 (11), 2121, 2015.

38. YUAN G., CAO Y., GLUYAS J., JIA Z. Reactive transport modeling of coupled feldspar dissolution and secondary mineral precipitation and its implication for diagenetic interaction in sandstones. Geochimica et Cosmochimica Acta. 207, 232, 2017. 41.

39. SANTONI S., HUNEAU F., GAREL E., AQUILINA L., VERGNAUD-AYRAUD V., LABASQUE L., CELLEJEANTON H. Strontium isotopes as tracers of waterrocks interactions, mixing processes and residence time indicator of groundwater within the granite-carbonate coastal aquifer of Bonifacio (Corsica, France). Sci. Total Environ. 573, 233, 2016.

40. PALMER M.R., EDMOND J.M. Controls over the strontium isotope composition of river water. Geochim. Cosmochim. Acta. 56 (5), 2099, 1992.

41. LI H., CAI C. Origin and evolution of formation water from the Ordovician carbonate reservoir in the Tazhong area, Tarim Basin, NW China. Journal of Petroleum Science and Engineering. 148, 103, 2017.

42. WIDANAGAMAGE I.H. Stable strontium isotope fractionation in abiotic and microbially mediated barite in modern continental settings. Dissertation, Kent State University, 2015.

43. RENOCK D., LANDIS J.D., SHARMA M. Reductive weathering of black shale and release of barium during hydraulic fracturing. Applied Geochemistry. 65, 73, 2016.

44. SCHOELLER H. Qualitative evaluation of ground water resources. In: SCHOELLER, H., Ed., Methods and Techniques of Groundwater Investigation and Development, Water Resource Series No. 33, UNESCO, Paris, 44, 1967.
45. XIAO Y., SUN D., WANG Y., QI H., JIN L. Boron isotopic composition of brine, sediments, and source water in Da Qaidam Lake, Qinghai, China. Geochim. Cosmochim. Acta. 56 (4), 1561, 1992.

46. XIAO Y., LI S., WEI H., SUN A., LIU W., ZHOU W., ZHAO Z., LIU C., SWIHART G. Boron isotopic fractionation during seawater evaporation. Marine Chemistry. 103 (3-4), 382, 2007.

47. NIR O., VENGONGSH A., HARKNESS J.H., DWYER G., LAHAV O. Direct measurement of the boron isotope fractionation factor: Reducing the uncertainty in reconstructing ocean paleo-pH. Earth and Planetary Sciences Letters. 414, 1, 2015.

48. RUIZ-AGUDO E., PUTINS C.V., KOWACZ M., ORTEGAHUERTAS M., PUTNIS A. Boron incorporation into calcite during growth: Implications for the use of boron in carbonates as a pH proxy. Earth and Planetary Science Letters. 345-348, 9, 2012.

49. DU Y., FAN Q., GAO D., WEI H., SHAN F., LI B., ZHANG X., YUAN Q., QIN Z., REN Q., TENG X. Evaluation of boron isotopes in halite as an indicator of the salinity of Qarhan paleolake water in the eastern Qaidam Basin, western China. Geoscience Frontiers. 10 (1), 253, 2019.

50. BOSCHETTI T., ETIOPE G., PENNISI M., ROMAIN M., TOSCANI L. Boron, lithium and methane isotope composition of hyperalkaline waters (Northern Apennines, Italy): Terrestrial serpentinization or mixing with brine? Applied Geochemistry. 32, 17, 2013.

51. LI T., LI J., MA H., LI B. Boron isotope geochemical study on oil-field brine in Western Qaidam Basin. Journal of Salt Lake Research. 21 (2), 1, 2013. 
